\title{
Film and Ritual \\ Epistemological dialogs between filmic anthropology and anthropological practice
}

Carlos P. Reyna - PPGCSO/IAD-UFJF

\begin{abstract}
This article discusses the dialog between filmic anthropology's procedures and methods and anthropological practice, with a focus on ritual, which is captured by the moving image in a more direct and fluid way. For this, the ritual of reproduction and preservation of cattle in Santiago, a peasant village in the Peruvian Andes is used as an empirical base. As an anthropologistfilmmaker I will try to make explicit the relationship between the observed process filmed and the informant, combining two important epistemological grids: Claudine de France's deferred observation, and Clifford Geertz's interpretation from the native's point of view. Finally, based on this experience, I will make some observations about the use of methodological approximations from filmic anthropology in anthropological practice, between film and anthropology.
\end{abstract}

Keywords: visual anthropology, anthropological practice; filmic anthropology, ethnographic film; ritual.

\section{Resumo}

O presente artigo trata sobre o diálogo de alguns procedimentos e métodos da antropologia fílmica na prática antropológica, notadamente em relação ao rito, o qual a imagem animada apreende de maneira mais direta e fluída. Para isso tomarei como base empírica o ritual de reprodução e preservação do gado em um povoado camponês dos Andes peruanos denominado Santiago. Nesse percurso, enquanto antropólogo-cineasta tentarei explicitar a relação entre processo observado filmado e o informante, conjugando duas importantes grades epistemológicas: a observação diferida, de Claudine de France, e a interpretação sob o ponto de vista dos nativos, de Clifford Geertz. Finalmente, baseado nessa experiência, levantarei algumas observações a respeito do 
uso das aproximações metodológicas da antropologia fílmica na prática antropológica, entre o cinema e antropologia.

Palavras-chave: Antropologia visual; prática antropológica; antropologia filmica; filme etnográfico; ritual. 


\title{
Film and Ritual \\ Epistemological dialogs between filmic anthropology and anthropological practice'
}

\author{
Carlos P. Reyna - PPGCSO/IAD-UFJF
}

\section{Introduction}

The methods used in anthropology to obtain data, even if they are constituted, as it were, by raw data, should always be analytically reconstituted. It is completely natural that fieldwork in the social production of knowledge requires a reexamination of the constitution of the information obtained. It is in this stage of the observation process that we pause to address the following questions: before elaborating on and describing the initial results of the sensory observation, shouldn't we verify that this observation was thoroughly performed? What instrumental or technical condition permits us to repeat, restore and thus verify the observed ritual process? We are referring to the introduction, to the tools of anthropological research, of videographic recording and reading devices. Film and video are operational media that lead us to new domains of anthropological study, from capturing subtleties imperceptible to the naked eye such as social relationships, to their use for recording ceremonies, dances or any complex event where many elements are in joint and or permanent movement. In this case, the difficulty of collecting data in order to reveal complex events - in our case, rituals - presents certain observational problems to researchers who do not use moving images. In

\footnotetext{
1 This article is based on my doctoral thesis conducted at Unicamp, and is corrected and expanded with data collected in subsequent studies in 2008 and 2011. For the anthropological interpretations, I suggest reading “O ritual andino Santiago - Uma reinterpretação etnocinematográfica,” Doctorate Thesis, Campinas, Unicamp, 2003; “(Re)interpretação antropológica do ritual andino Santiago" in Resgate - Revista de Cultura, Campinas: CMU/Unicamp, n ${ }^{\circ}$ 12- 2003, pp. 23-41, and "Os deuses da montanha do Peru contemporâneo" in Cadernos de Antropologia e Imagem, RJ, PPCIS/UERJ, 2006, pp. 137-153. It is not the intent of this article to describe the reinterpretations of the ritual, its main motivation is to present the methodological procedures we used to imagisticly record the ritual process and try to find, in the particularities of the filmed observed process, the source of the narrativity itself that we needed to understand our process of observing the Andean Santiago ritual process.
} 
this situation, the "raw" field book and memory come to be, as a set, highly incomplete and inadequate. Videographic techniques have the particularity of allowing anthropologists to permanently capture an entire flow of perceivable activities that can then be repeatedly verified and analyzed by the researcher, the informant and the two together, in the field or in the laboratory. For this reason, these techniques allow new discoveries.

According to Claudine de France, ${ }^{3}$ the opening of a new relationship for exchanging information, thanks to the potential of this new medium, yields a new proposal in anthropology called the exploratory procedure:

Three types of facts appear to be at the origin of the generalization of the exploratory procedure. They are: the existence of repeatable processes; the technical possibility of repeating the continuous recording of these processes; that of repeating, at the location of filming itself, the examination of the image, that is, the deferred observation of the studied process. (1998: 342).

That is, from the moment at which it is possible to repeatedly reproduce the continuous flow of the process studied and freely observe its image - that which is perceivable and filmed can be replayed - de France raises the following questions: why would a researcher persist in using as a reference that which is only immediately perceivable and which cannot be replayed? And why would he bother with direct observation prior to recording the process? David MacDougall, attentive to these qualities of film, mentions other characteristics:

The perfection of the film image impresses us, in part by the precise retribution of detail, and even more because it presents a continuum of reality that is extended beyond the limits of the frame, which paradoxically, does not seem to be excluded. Few images create a world. (1998: 132)

2 "Raw", an expression used by Clifford and Marcus (1986) to describe a block of notes, in reference to the studies of Mead and Bateson in Bali. Taken from the essay of JANCKINS, Ira. "Margaret Mead and Gregory Bateson in Bali: Their use of Photography and Film", in Cultural Anthropology, Washington (American Anthropological Association), Vol. 3, N² 2, 1988, p. 160.

3 From the point of view of the introduction into research of different technological media, we use some proposals from the Training in Cinematographic Investigations of the University of Paris X, Nanterre. In addition to producing documentary films, these studies consider the images in motion as the object of investigation in the first plane. Cinema e Antropologia (1998), by Claudine de France, is the main point of interest of a set of studies and looks at the methodological issues subjacent to any filmic recording of anthropological nature. Exploratory research is the most significant proposal and led us to articulate the procurement and interpretation of ethnographic data by various processes. 
It is these filmic functions ${ }^{4}$ and significations that encourage us and steer us in another direction, leaving aside the traditional and classical forms of data collection.

Historically, there were many pioneers who used moving images to document what were understood at the time to be little evolved societies. The production of documentaries made them precursors to the transformation of classical methods of anthropological research. Among the most often cited and well-known of these pioneers, Robert Flaherty - considered the father of anthropological film - shot the daily life of the Nanook Eskimos. An essential part of his method consisted of filming and immediately developing - at night in an improvised laboratory - and then projecting the images recorded that day for his subjects to see. This gave rise to what Jean Rouch would call "the invention of our entire ethic," in response to his principal concern: "How can we film people without showing them their images?" (REYNA 1997). It is from this shared or participatory ${ }^{5}$ observation that mutual collaboration between the people filmed and the anthropologist-film-maker is established. The immediate and direct participation of the people observed in the recording constitutes the singularity of this research method, because it increases the joint field of observation analysis and interpretation. This is especially true when what is observed are rituals accompanied by vigorous non-verbal behaviors. In these cases, film becomes the most efficient tool for recording, analyzing and reinterpretation.

\section{Methodological dialogs between film and the Santiago ritual}

As in the Auray ${ }^{6}$ peasant community studied here, the indigenous

4 Another special function of the method of ethnographic film in the rituals is well understood, in the capacity to capture the subtleties imperceptible to the naked eye, in which many elements are in joint, permanent and/or repetitive movement. Film enables us to record the continuum, the nuances, the subtleties and the condensed data from and in the ritual process to unveil the several forms of meaning. See Claudine de France (1989); Barry Machin (1988); Carlos Reyna (1996); Marcus Banks (1998); Howard Morphy (1994).

5 Definition used by Jean Rouch, citing Luc de Heusch, to categorize the participating camera as a third person in the relation of information exchange. Jean Rouch, "La câmera e les hommes" in Claudine de France (org.) Pour une anthropologie visuelle, Paris, Ehess, 1979, p. 56. This feedback is also called by some authors the mirror-effect, Jean Rouch calls it anthropologie partagée (shared anthropology).

6 The Auray peasant community is in the far south of the Rio Mantaro Valley, in Huancayo provincein Peru's Central Andes. It is $3,218 \mathrm{~m}$ above sea level and is composed by approximately 1800 people. Its main activities are planting and cattle raising. While its transformation is increasingly more intense due to 
communities of the central Andes have many festivals and rituals. Each agrarian moment is celebrated, the celebration of the cattle and their patron saint usually the apostle Santiago. Although it seems to be, the commemoration of the apostle, the festival of Santiago, is not a Christian celebration. Catholic clergy do not participate in it nor are prayers directed to God, the Virgin Mary or the saints. Even though Santiago has an altar in the local church, it is not visited in particular at the time of the festival. The ceremonies do not have the community character of patronal festivals or of the main religious celebrations. The main personality of the commemoration is Wamani. The rituals are offered to him and their main purpose is the preservation of and increase in the number of cattle (cows, sheep, horses, mules, pigs, etc.) According to historian and ethnologist Sérgio Quijada (1974), the festival of Santiago is considered to be a day for animals and shepherds, which is based on the belief in Tayta Wamani as the god and master of the mountains. Saint and mountain can be seen as equivalents and are treated as two aspects or names of a single force. It is customary to think that the natives worship the mountains, whereas this celebration, in reality, is not directed to the place, but to the spirit that inhabits it, consecrated as hierophany. ${ }^{7}$ The Santiago festival was not introduced by the Spanish, but upon their arrival the natives attempted to continue celebrating their animals, under the tutelage and protection of the apostle of that name. Regarding the rules and ceremonies observed during the Sanitago festival, those responsible ${ }^{8}$ for the celebrations (Fig. 1) usually comply zealously with traditional indigenous customs.

Thus, it is the ritual gesture that establishes relationships of alliance or tribute that are paid to a being considered to be superior. This gratuitous donation is the acknowledgement of a power superior to human

the penetration of different means of production, circulation, consumption and communications, its life style is still rooted in traditional ancestral molds. Some historians state that in the past the wancas and the Incas inhabited this region, but this did not have a specific name. The lands belonged to the Inca and to the god Inti (Sun). With the arrival of the Spanish, these ancient inhabitants began to give up their gold and silver artifacts to keep them from falling into the hands of the conquistadores. We can also find vestiges of pre-Hispanic constructions of cities called Wuari-Vilca and Quillis Qocha. The Auray still conserve fragments of their traditional forms of communal organization, since they were not affected by the 1969 agrarian reform.

7 According to Mircea Eliade, hierophany is the manifestation of a sacred entity. See O Sagrado e 0 Profano: A essência das religiões. São Paulo, Martins Fontes, 2001.

8 Cattle owners, responsible for the ritual and the principal informants of the study, constituted by the Torres Orellana family: Juan Torres (husband), 78 , and Julia Orellana (wife), 73. 

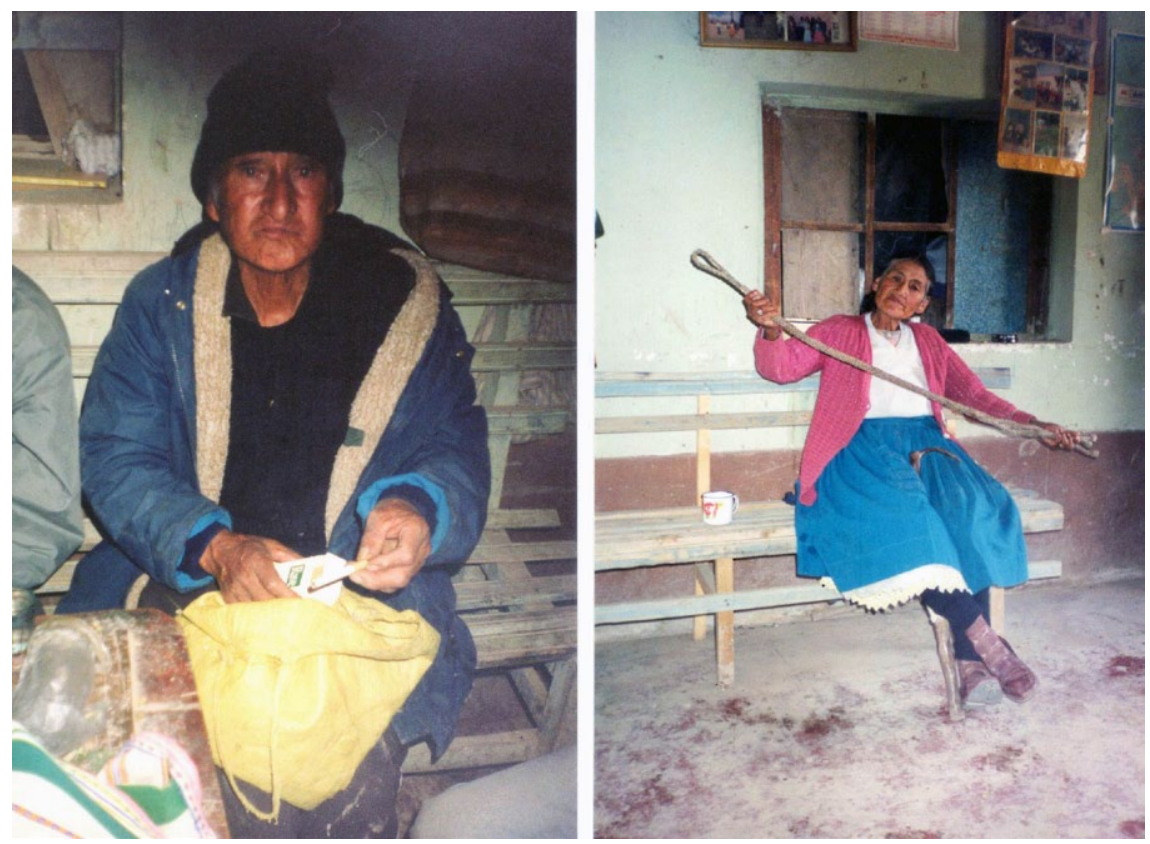

Figure 1: Informants: “Don” Juan Torres and Julia Orellana / Photo: Carlos P. Reyna, 2003

forces, a request for communion or atonement for some failing that, in some way, questions relationships among men or between human beings and superior beings.

In this position, the Andean Santiago ritual presents us with a problem of the relationships of correspondence between the representation (images, signs and symbols) of time and space, of gesture and words and of myths and rites that the Santiago festival expresses each time it is performed. Its dramatic character reveals that somehow the ritual gesture wishes to achieve the event or act as a totality. To understand the ritual, it is thus necessary to study the cultural world of the Central Andes of Peru, beginning with the representation of time and space and their relationships with gestures, words, myths and rites. From this perspective, we will look at the Santiago ritual as a web of meanings that we will analyze, to understand the subjects of action, given that they demand an interpretation. That is, we look at the ceremony in its social discourse, according to the teachings of Clifford Geertz (1980, 1989, 1997).

On this basis, we can raise an important methodological question: how can we apprehend and restore the ritual dimension that we propose in this study? Two aspects led us to the choice of our research tool. The first was 
the dramatic nature of the ritual being studied. In a diffuse or patent manner, the Andean ritual is a spectacle of gestures, objects and manipulations that humans offer to their gods or that they offer among themselves. As fleeting as words, the ritual gestures need to be kept in memory to be able to affect the senses or impress the gods, according to Jean Cazeneuve, hence we see them regularly repeated ${ }^{9}(1971: 16)$. The second aspect is the approach to the hermeneutic of Clifford Geertz. In the chapter about "Person, time and conduct in Bali," in The Interpretation of Cultures (GEERTZ 1989:225-277), and in the essay "From the native's point of view: on the nature of anthropological understanding" in the work "Local Knowledge" (GEERTZ 1997:85-107), the author presents a unique anthropological approach from the point of view of the informants. Differently from the semi-chameleon researcher Malinowski (1976), who, thanks to some kind of almost supernatural sensation thinks, feel and perceives the world as a native, Geertz insists on a methodological question that anthropologists see the world from the points of view of the natives (emphasis ours). To do so, Geertz uses the concepts of close experien$c e$ and distant experience to define the relationship between the subject (researcher) and the object (informant). A distinction that Clifford Geertz borrows from psychoanalyst Heinz Kohut:

A concept of "close experience" is one which someone - a patient, a subject, in our case an informant - would use naturally and without effort to define that which his peers see, feel, think, imagine, etc., and that he himself would understand easily, if others used it in the same manner. A concept of "distant experience" is that which specialists of any kind - an analyst, a researcher, an ethnographer, or even a priest or an ideologue - use it to carry out their scientific, philosophical and practical objectives. (1997: 87).

That is, there is a clear degree of differentiation between what is seen, perceived and signified to the informant (the object of the research) and what is seen, perceived and signified to the researcher (the subject of the research). However, because this difference is not normative, one of the concepts is

9 The communication media, in contact with anthropology, sociology and history, are among those that tend to make us believe that all repetitive behavior is ritual. Is the act of teeth brushing a ritual? And if the simple repetition of behaviors were sufficient to defining a ritual, then we could say that animals also have ritual behaviors. Therefore the repetition of an action is a necessary but not sufficient condition for defining a ritual. 
not necessarily better than the other, neither is it correct to prefer one to the other. The true issue, in the case of the "natives," is that it is not necessary to be one to understand them. To know how people present themselves to themselves and others it is necessary to adopt a methodological approach that evolves by means of dialog between the interpreter (researcher) and the Other (informant). From this information exchange, one searches for and analyzes, in one's experiences, the observable symbolic forms (manifested or hidden) of others with respect to their own conception.

Thus, given the two aspects of the ritual dimension of the Santiago, we believe that the moving picture is one of the most apt instruments to both capture its condensation (dramatization) and to question the informants (methodology). This is because film, in the case of the first aspect, enables the recording and restoring of the space-time continuum delimitation of the direct ephemeral manifestations (ritual gestures, words and manipulations) and of the indirect manifestations (objects and traces of the ritual activity). And, in terms of the second aspect, a point of dialog is established with hermeneutics, which Geertz called the "understanding of cultural understanding.". That is, concerning the filmic description of what is observed and filmed , ask the informant about the symbolic forms present in the image. What is important to us is to discover together with the informants "what the hell they think they're doing" (GEERTZ 1997: 89). Therefore, moving pictures - in this study - establish the relationship between what the informant sees, feels perceives and gives meaning to and what the researcher sees, feels, perceives and gives meaning to. The appearance of these interpretive approximations in opposition to the dominant orthodoxy of the positivist tradition enables the researcher to go beyond the simple subjacent structures of the ritual and conceive it as a negotiation of meanings. In this way ethnographic description becomes a process of describing and elucidating these performances instead of demonstrating their function or role in an abstract system. Therefore, we reiterate: to study and reinterpret gestures, words and rites inserted in the representation of time and space in the Santiago festival we shall do so with and in film. Another reflection from researcher Claudine de France strengthens our proposed methodology when she says that "The study of man by film means not just the study of filmable man - susceptible to being filmed - but, equally, the filmed man, as he appears placed in the scene by film" (2000: 18). 


\section{Issues of method: insertion and strategies of observation.}

In each filmic recording process, many anthropologists develop different ways of understanding the ritual, based mainly on some traditional methodological postulates of field research. As Luc de Heusch observes:

We perceive poorly how cinema could be, in the realm of social phenomena, a generalized research tool, an instrument for discovery: the camera is certainly a witness, though an exterior and stupid witness, unless a cautious eye, a human eye that has already seen and is prepared to recognize, guides it with ability and sensibility in the recording of the testimony(1962: 24).

This behavior of the filmmaker anthropologist is based on the methodological principle that he cannot film without first having resorted to the use of direct observation, thus making this a reference for any other form of observation. Therefore, filmic representation would represent, in its own way, the direct observation of that which constitutes a montage of the most significant and or spectacular moments. Another attitude is taken when the anthropologist and filmmaker have separate roles in the filming, to wit: the filmic process, in which the anthropologist provides the filmmaker with the necessary information about what he should record, requires that he have knowledge of what is to happen, that is, the meaning of the events, where they happen and who are the actors of ritual significance (LYDALL 1992). Accordingly, knowing the sequence, the anthropologist would supply a commentary beforehand, which determines what shall be filmed. In the case mentioned, the potential of film would be used for purposes other than that as a methodological tool for discovery, with its objective being another kind of exploration and exposition.

In our case, it is necessary to stress that the investigation is built from film, from the recording experience and from repeated examination beyond any extra-cinematographic preparation. Therefore, we will now highlight both methodological options available when realizing videographic recordings as well as strategies for filmic observation and analysis of the ritual cattle-branding process in Santiago in the Auray peasant community, in the Central Andes of Peru. With a concern for describing the ritual process, we restrict ourselves to two fundamental aspects: a) the insertion phase; 
b) the composition of the liminal phase ${ }^{10}$ and its mise en scène, best defined by Claudine de France as a filmic representation or "set of laws by virtue of which is defined what the moving picture necessarily allows any spectator to see, and more particularly the anthropological spectator" (1998: 20). For a better understanding of the circumstances of the imagistic recordings of the Santiago ritual, we will differentiate each of these phases:

\subsection{Insertion: preliminary phase}

All the knowledge that we had about the ritualistic activities of Santiago is expressed in particular studies from other times and other regions of the Vale do Rio Mantaro. Thus, together with the anthropologist Juan Carlos Cóndor, ${ }^{11}$ one week in advance, we made preliminary contact with both the representatives of the Auray peasant community and with the Torres Orellana family, which was chosen for being the family in the community that still preserved forms of cultural continuity of the Santiago ritual. Once contact was made with the Torres Orellana family, we defined three criteria that would guide this phase. These include: a) making the necessary links with the participants of the ritual concerning their customs, routine and dialect, that is to say, the scope of the activities; b) convincing the Torres Orellana family of the importance of their cooperation, both for making the film and for further research and; c) knowing the space-time demarcations of the ritual to establish parameters for conducting the videographic recordings.

Thus, we spent the two days prior to the ritual process eliciting the information and conversing with the participants about the previously mentioned criteria. From that point of view, this insertion phase enabled us to unveil three relevant issues.

a) The first is that although the systematic imposition of terror by the "Shining Path" sociopolitical movement left vestiges of anguish and fear in

10 For the use of the term "liminal" I refer to the studies of Victor Turner on rituals. Turner renames the three steps identified by Van Gennep, separation, transition and reincorporation as preliminaries, liminaries and post-liminaries. For Turner, rituals are equivalent to a data element (individual, group, society or object) that passes through certain formal and ceremonial sets. See the classic text $O$ processo ritual: estrutura e antiestrutura, Petrópolis, Vozes, 1978.

11 The anthropologist Juan Carlos Cóndor Ames is a specialist in Andean worldview, professor at the National University of the Center of Peru (UNCP), in Junín State, a province of Huancayo. He is the author of several studies on the subject, and is currently studying the Andean worldview. His knowledge of the Quechua language permits associating the ritual gestures and sequences with the corresponding times. His support, companionship and information about the community studied were essential to this study. 
the region, the family members had a certain familiarity with the research tool. That is, several TV channels regularly made journalistic videos about the Andean world. The city of Huancayo, because it is a city with a preColumbian and colonial historical past, and because it is close to Lima, the national capital, stimulates both journalism and tourism. Thus, these two activities are frequent in the city. From these experiences, notions of journalistic reporting were created among the family members, and they therefore initially thought that the filming would consist of another interview to be conveyed by some local or national TV channel. This gave us the opportunity to reveal that the use of film would not answer the methodological options of exposition or recognition of direct observation, but of exploration, of discovery. According to Claudine de France, two principles appear to emanate from the exploratory procedure ${ }^{12}$ :

The first is the substitution of the immediately observed, the object of the direct apprehension, by deferred observation, because it is filmed. The latter, which results from the former, is the suppression of direct observation as an indispensible preliminary step for the study; or, what becomes the same thing, introduction of the filmic recording before any in-depth observation. Therefore, deferred observation substitutes immediate observation in the indepth examination of the process; the cinematographic recording, support for the deferred observation, becomes the first act of the investigation. The film opens the study. The interview with the people filmed and the inquiry of the informants are supported in the examination of the recording and are no longer a preliminary step in the filming, they are deferred. (1998: 306, 342).

b) The second important issue we raise, a priori, involves the elementary notions of the first difficulties that we encounter in the anthropological process as filmmakers. ${ }^{13}$ These difficulties concern the instrumental, spatial and temporal contingencies of the ritual process. First let us look at the temporal issues. While our intention was not to film the ritual in real time, knowing

12 The rise of magnetic means of recording images and sound (videographic techniques) that allow substituting the simple exposition of the results from direct observation by a deferred observation (strategy or exploration, of discovery).

13 A practice of the anthropologist/filmmaker to emphasize the unfoldings and procedures that the anthropologist performs with the filmmaker to choose, encircle, delimit and follow our filmic research objective. 
that the videographic recordings would not have a continuous sequence, ${ }^{14}$ the fact that Santiago is conducted on different days allowed us, in addition to making a provisional schedule of the sequences of the ritual, to recharge the batteries in the middle of the recording (the video). On the other hand, the initial inquiries made in this phase of the insertion indicated that the movements and disposition of the participants in different ritualistic spaces would force us to seek means of overcoming the technical limitations of the videographic recording device. ${ }^{15}$

c) The third issue is that of dealing with a seasonal ritual. We know from our previous studies and information provided by our informants (Donna Julia Orellana and "Don" Juan Dorres), that the Santiago celebrations are performed in July and August. As a ritual involving the reproduction and preservation of cattle, these months represent an intermediate cycle between the dry and the wet seasons and coincide with the lack of good pasture. Thus, the reproductive cycle of the herd it would only resume in the next rainy season . Therefore, as with Jean Rouch in the film Architectes ayorou ${ }^{16}$, our videographic recordings of the Santiago ritual penetrate the partial and private universe of the exploratory procedure. This procedure concerns the result of a single filming performed without direct observation and is made up of long, continuous sequences.

\subsection{Filmic strategy: filmic observation guide}

It is important to remember that the recordings of the ritual require particular methodological procedures and field practices that enable both the

14 We knew that we would not have access to the ritual unit called Pagapu, because according to "don" Juan only those who make prayers and requests should have access to the place where the huacas are hidden. According to the Inca Garcilaso de la Vega, "huacas are small idols that are offered to the sun, figures of humans, birds and animals, made of gold, copper or wood, and anything else sacred offered, because they were sent by the sun, they belonged to it, and had strong veneration for it" (1970: 80). About the Pagapu ritual unit an interpretation was given to us by our informants on page 12.

15 The choice was also made as a function of a kind of recording style that only light equipment "sees," because it is fast and moves. That is what allows the movement.

16 Architectes ayorou, $16 \mathrm{~mm}$, color, 30'. Because of the continuity of the recordings, the film simultaneously reveals the diversity and the simultaneity of the architectural and everyday activities of the Ayorou. 


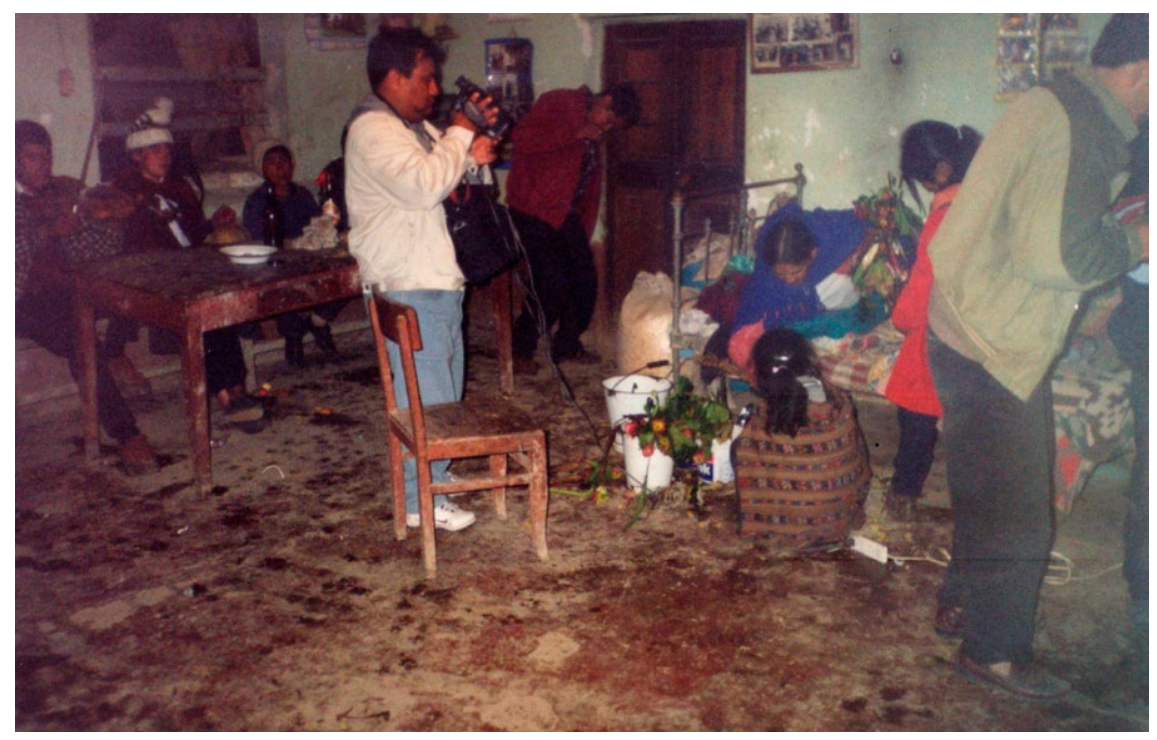

Figure 2: Filmic recording of ritual / Photo: Juan C. Ames, 2003

anthropologist and the filmmaker ${ }^{17}$ to be combined in a single person: $\mathrm{me}^{18}$ (figs. 2 and 3) But what type of relationship is put in practice each time the Santiago ${ }^{19}$ ritual conditions are performed? As in any other kind of religious scheme, the Andean man dramatically performs his intentions, or more profoundly, his own consciousness of the world and of things, systematically invoking, and following the logic of ritual gesture, the beings or a being in particular, in which it is believed that the perfect realization will be found.

17 I believe that this distinction goes beyond those made by Jean Rouch, Luc de Husch and Claudine de France. The dual role of the researcher and the position each exerts on the anthropological practice are intimately related not just to the practice of the anthropologist as an observer, but to the practice of the anthropologist as a filmmaker. At certain moments of this practice, the overlapping is necessary, due to the unfoldings of the ritual.

18 Any methodological attitude and any movement of the filmmaker should be associated to the ritual, better said, to the movements of the beings participating in it. They are procedures that the filmmaker adopts as an observer of the ritual process. Therefore, decisions, successes and failures are deliberations specific to the filmmaker/anthropologist.

19 One of the main objectives of this study was to contemporaneously reinterpret with and in film the Andean cattle branding ritual known as the Santiago. That is, in the viewing and in the deferred observation of the images together without our informants, to discover the meaning of several components and ritual units, in order to then consider their arrangement within the ritual as a whole. Therefore, the ritual cannot be considered simply to be the succession of its units, components and elements in time, since it also takes place in space. Thus, I tried to examine the meaning of this succession in time, as well as the simultaneity of its manifestations in space. The ritual gestures and movements of the participants are accompanied by dances and chants that were also considered. I believe this is one of the reasons that our informants did not know how to precisely define the meaning of the Santiago ritual. 


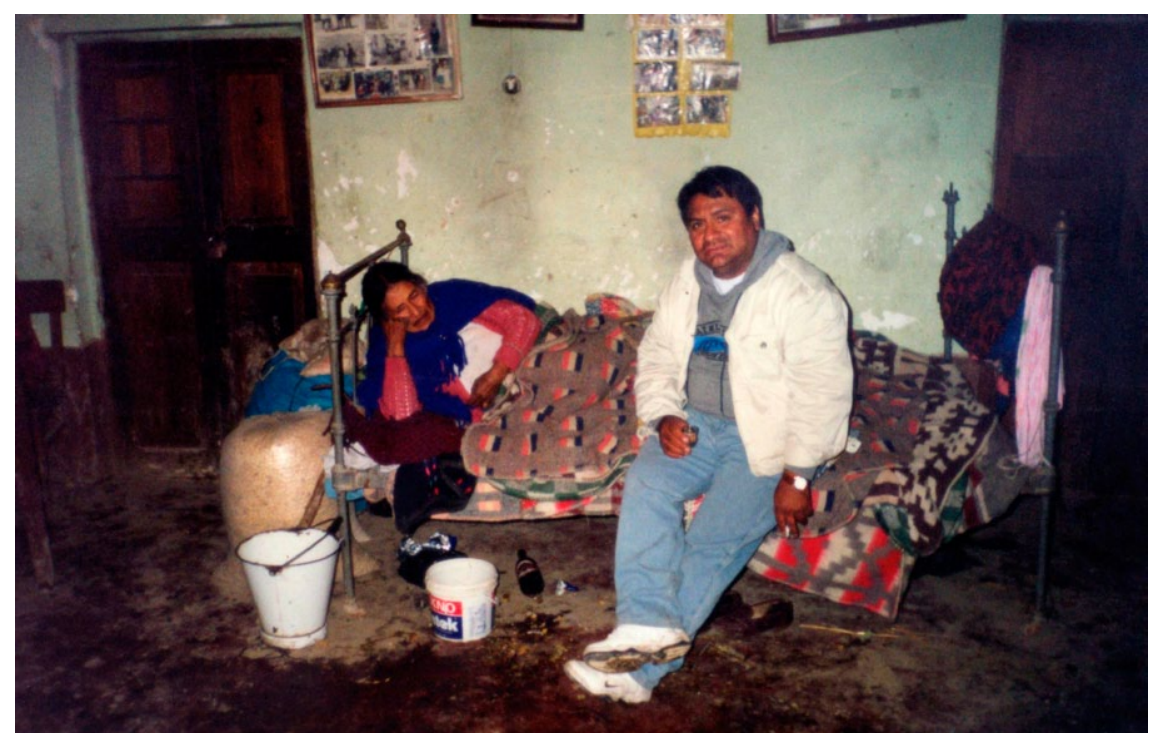

Figure 3: Taking a break with Mrs. Julia Orelhana / Photo: Juan C. Ames, 2003

An example of this was given to us by the testimony of dona Julia Orellana when speaking about the preparations for Pagapu ${ }^{20}$ :

The Wamani lives in the mountain, we must give the kintu (fee) for the animals that we have, with chicha, wine, ribbons, corn, small clay images and other things inside a small earthenware pot we bury in his place (...). It is almost always Juan who buries it, other people bury these offerings in pairs, sometimes one, it's dangerous, anything can happen or appear.

She tells us nothing about the invocations performed; she keeps the request that is made to the mountain to herself. However, later, Juan Torres, manifests: "I ask the Wamani to increase my herd and that they not get sick or die." We thus perceive that by establishing a relationship with the gods of the mountain [Apu (mountain) - Wamani (god of the mountain)], the Andean man, with his ritual gestures, celebrates covenants or pays tributes, reflecting a pact or the simple expression of an intimate union between beings that inhabit the same community space.

In this praxis, we, as filmmakers/anthropologists, aware of the ritual relationship mentioned above, try to extract the components of this

20 The ritual unit of ritual of the offering to the Wamani is made any day after the central day (see page 16). From the information in footnote 14, we knew that we could not have access to this ritual unit. This was particularly important because it enabled us to design our filmic recording strategy of the ritual. 
communication system and we find it convenient to apply, both to the observer and to the protagonists, a function in each case: addressee/superior being and addresser/human being. According to Luc de Husch, attentive to the function of ritual communication, the notion of addressee occupies a central place (1974: 696-697). This distinction of functions was important for the elaboration of our videographic strategy. As mentioned in the testimony of dona Julia Orellana and "don" Juan Dorres, the (Apu-Wamani) is the god of the mountain. Therefore, the Wamani becomes the addressee, by being the first element of reference and orientation, the addressee that involves the perception of the ritual. This relationship of communication between the human beings (dona Julia Orellana and "don" Juan Dorres) and their gods (Wamani) helps support our use of the definition of addressee provided by Claudine de France: "A critical or complacent spectator that the participants spontaneously appreciate. All of their acts converge on him; they engage in a gestural and/or verbal dialog with him whose material is given to us by the practices of the ritual." (1998: 98). De France raises three features of auto-mise en scène $e^{21}$, defined as follows:

Visible or invisible, omnipresent or oppositely materialized in an incarnated object, be it in a person, be it in several members of the group; an outside observer or one engaged in the action, and even internalized by the agent(s) of the ritual. (DE FRANCE 1998: 99).

If these traits of auto-mise en scène indicated by the quote permit us to define the observer - a visible or invisible being or beings - as the addressee of the filmic observation, what role do(es) the agent(s) of the actions play in relation to the presentation of the Santiago ritual? According to de France, ritual techniques obey a scheme of practical functions in which the agent of the action, accompanied by his ritual device (corporal and material instruments, immediate objects), appears on the scene, as a presenter, on behalf of the observer of the ritual, that is, the addressee. Analogously, this same

21 "An essential notion in documental cinematography, which designs the various manners by means of which the observed process presents itself to the filmmaker in space and time. This mise en scène itself is autonomous, whereby the people filmed show, more or less ostensibly, or obscure to others, their acts and the things they involve, throughout the corporal, material and ritual activities. It is, however, partially dependent on the presence of the filmmaker. Auto-mise en scène is inherent to any observed process. Equally, it should not be confused with self-highlighting, which is only one of its specific forms." See Claudine de France, Cinema e antropologia, Campinas, SP, Unicamp Press, 1998, p. 405-406. 
presenter (the agent of the ritual, executor) is converted into the object of observation for the addressee. According to de France, "addressor and addressee are simultaneously invested with dual functions within a relationship of reciprocal dissymmetry between their functions" (1998: 96). Thus, this reciprocal relationship between addressee and addressor appears to us to be the principal strategy and ritual observation guide.

In addition, this same complex scheme of functions and ritual presentation offered us an auto-mise en scène that guided us through the apparent lack of order of the human activities of the Santiago ritual. Thus, what posture would we have to adopt in relation to the Santiago ritual process to be observed? In our case, it was necessary to adopt some methodological attitudes. The circumstances of the ritual process provided us a set of options. At times, this great multiplicity of aspects and relationships demanded we use a broad framing; at other times, to the contrary, it fragmented the framings in a succession of fixed shots, separated by spatial jumps to encompass the relationship between the addressee and the addressors.

With respect to the temporal procedures (the approximate amount of time needed for observation), we stress, essentially, the existence of a base duration ${ }^{22}$ that "corresponds to the period of action during which the agents let themselves be seen and heard by any addressee" (De FRANCE 1998: 409). That is, the filmic time of the ritual is, above all, the duration that the agent(s) use(s) in the ritual activity itself. Thus, in our videographic recordings of the Santiago ritual process, our desire to describe was manifested in the care with which the filmic mise en scène of the ritual and its dominant ritual ${ }^{23}$ were made to coincide. So, the rhythm, the duration, the form of

22 "A temporal equivalent of the delimitations based on space (base framings and angles), the duration of the base corresponds, in relation to a given conductor, to the duration of the recording necessary for learning the essential phases of a process. For example, the activities that unfold at the center of action of a ritual - not backstage - for a ritual technique..." See Claudine de France, Cinema e antropologia, Campinas, SP, Unicamp Press, 1998, p. 409.

23 "Both in the image and in direct observation, human activities are always developed simultaneously at the level of the body, of the material and the ritual, this triple development is made, in the majority of cases, for the benefit of one of these three aspects. One of these three aspects not only dominates the others, but also relationships of hierarchical subordination are established among them in which each, executing the dominant aspect, is at the same time the end of one and the means of another. The dominant aspect of the process is, finally, that which expresses its main purpose, and whose program commands the auto-mise en scene of the set." See dominant ritual in Claudine de France, Cinema e antropologia, Campinas, SP, Unicamp Press, 1998, pp. 93-132. 
sequencing and of ordering the ritual activities required imagistic recordings of the condensed continuum of the agents' activities in the ritual phases and not fragments or intermittent takes of the spectacular sequences of the ritual activity. In this continuum we include backstage ${ }^{24}$ elements of the ritual (depicting gestural and verbal repetitions, preparations of the ritual materials, unexpected and/or "profane" behavior of the agent(s) and/or participants between the pauses and/or "sacred" phases of the ceremony). In our case, the imbrication between the ritual and its backstage, between ceremony and everyday, in addition to being revealed as an effective element for bringing to light new significances of the (re)interpretation of the Santiago ritual, grants the researcher and the spectator several possibilities for access to knowledge of what is most intimate in the observed process. It is necessary to mention that of the three successive phases directly necessary for understanding the Santiago ritual: the preparations, the eve and the main day, two deserve our filmic observation, the eve and the main day. The preparations, which include acts composing the preliminary ${ }^{25}$ phase of the process, are not considered part of the Santiago ceremony, not only because they involve purchasing and preparing the "ingredients" used in the festival (chicha [fermented corn alcohol, wild fruits and flowers), but also because their cultural continuity is diluted in the industrial process in which they are produced. Considering this finding, we see that the temporal chain ${ }^{26}$ of the sequential relationship between

24 A concept used in one of our previous papers that concerns everything that is not found recorded in the images, such as notes from the verbal dialog that is established between the people filmed and the filmmaker and the different interpersonal relationships of the participants originating from the ritual course etc. Carlos P. Reyna, A memória e o gesto, Campinas, Masters dissertation, Unicamp, 1996, p. 134.

25 For the use of the term "preliminary" I refer, again, to the studies of Victor Turner cited in footnote 12.

26 "A notion of logical-scenographic order that designates the manifestations of the filmed process relative to its internal articulation, existing both in space and in time. Indeed, the spatial chain results from a relationship of contiguity not only manifested (scenographic), but necessary (logical), for reasons of physical or ritual order, between the elements of the process (agents, device); the temporal chain, on the other hand, consists of a relationship of immediate attainment, which is equally necessary (or obligatory), between the successive phases of the activity (gestures, operations) of the agents engaged in the process. The concept of temporal chain is inherited directly from the concept of "operational chain" created by A. Leroi-Gourhan (1965). It is important to note that the mandatory relationships of contiguity (spatial chain) and of immediate attainment (temporal chain), purely anthropological, are relatively independent: restrictions (physical) and rules (ritual) of composition implying the mandatory presence of some human or material elements of the process in space, in the same way as some phases of this process in time; restrictions and rules of ordering implying the orientation, the space, of the elements of the process some in relation to the others, thus like the order of succession, in time, of the phases of this process." See Claudine de France, Cinema e anthropologia, Campinas, SP, Unicamp Press, 1998, p. 406. 
the preliminary phase (the preparations) and the liminal phase (the eve and the central day) is not necessary for understanding the process. The absence of filmic recordings of the preparations does not compromise an understanding of the progress of the ritual, because it is a phase whose original gestures and operations were substituted by the simple practice of acquiring products at the central market in the city of Huancayo. We therefore considered its recording to be unnecessary. Thus, faced with the evident traces of cultural discontinuity of these preliminary acts (the preparations), Juan Carlos Cóndor, who has considerable experience with and is well versed in the Andean people, suggested that we bring some of the "ingredients" ${ }^{27}$ - which in the past were ritualistically prepared - as a contribution to indicate our appreciation for the willingness of the Torres Orellana family to permit us to imagistically record the elaboration of the Santiago ritual.

\section{Filming the Santiago Ritual: the liminal phase}

The videographic recordings began in this phase, that is, the research began with filming. Therefore, let us remember, our main goal was expressed in the concern to adjust our presentation (mise en scène) to the self-presentation (auto-mise en scène) of the filmed activity. In other words, gestures, activities, behaviors, etc. are subordinated to the ritual program that commands their general execution: the rhythm, the duration, the rules of composition, the sequencing and the order of the phases of the ritual spectacle.

To establish a sequential of the various intra-phases of the Santiago ritual, we turned to Victor Turner's (1974) concept of the ritual unit, as previously mentioned. Thus, the liminal phase is constituted by the following ritual units:

a) The eve, July 25 , on which the following ritual units are performed:

- The Tinyakuy: music and songs special to this festivity.

- The Huaca-Jorqoy: (removal of the huaca ${ }^{28}$ buried the previous year).

27 This included five packs of cigarettes, two liters of "chicha jora" (fermented corn), two liters of "sugar cane alcohol" (cachaça), two dozen ribbons of colored wool and wildflowers. Today, in the city of Huancayo, at the Santiago festival, a street near the central market is dedicated exclusively to the sale of these "ingredients."

28 According to Mario Polia Meconi, the concept of the huaca (wak'a) is one of the original concepts of Andean religious though. A literal translation of the word is impossible. The gender of the word can be masculine or feminine, according to the place or object and the spiritual entity related to it. In literary use and in the Spanish spoken in the Andes huaca is usually used in the feminine. La cosmovisão religiosa 
- Miskipada: a pseudophase between the ritual units for chacchar (chewing coca leaves), sipping cachaça, dancing the Santiago songs or simply resting.

- The Velakuy (veiled): setting the table and changing the ritual elements placed in the huaca the year before with new ones. Realization of the walks.

- Miskipada and Tinyakuy

b) The main day, July 26 .

- Tinyakuy

- Luci-Luci: (saumar) scorching the womb of the animals with lit hay.

- Visitakuy (visit) and Tinyakuy: moment of going to the house of dona Julia Orellana's sister, dona Mirta, to get her to participate in the festival.

- Miskipada and Tinyakuy

- Preparation of the Ritual Table: chacchar, the kinto (choice of the best coca leaves) and making and choosing wool ribbons for each animal by dona Julia Orellana, her sister and grandchildren.

- Cintachikuy: putting the colored wool ribbons on the cattle..

- Casarakuy: figurative marriage between the young (walars) and the vaquilhonas. $^{29}$

Considering these sequences, the Torres Orellana family subtly imposed on us, a provisional distancing, intervals (pauses) between ritual units, between one day and another. The question arose how would we realize the filmic sequencing of these separations or pauses between the ritual units, between one day and another? We know that the possible forms of conducting this sequence include the use of modes of articulation ${ }^{30}$ in the space of time between the phases and intra-phases of the ritual. If, on one hand, the absence

andina en los documentos inéditos del Archivo Romano de la Compañia de Jesús (1581-1752), Lima, PUCP, Fondo Editorial, 1999.

29 Cows that have not given birth.

30 "These modes of articulation are differentiated among themselves by the obligatory or optional nature attributed to the pauses or the relationships of attainment between the units of ritual or intraphases of the ritual process." See Claudine de France, Cinema e antropologia, Campinas, SP, Unicamp Press, 1998, p. 193-304. 
of a mandatory sequence between the preliminary and liminal phases of the process is evident, the same does not occur with relation to the moments that make up the liminal phase. For this reason, it is necessary to pay attention to the intervals realized during the course of each ritual unit. In this way, the pauses between the activities performed, which offer certain interruptions in the passages between ritual units, are expressed by the following indices:

1. We knew from the insertion phase that it would be necessary to discontinue the videographic recordings of the ritual process for several reasons. Three passages are provided for these interruptions. The first, on July 25 , the eve: the recordings began around 3:00 PM, and we were able to film the following units of ritual: the Huaca-Jorqoy, the miskipada and the initial part of the Velakuy; the interruption took place at the peak of the participant families' drinking and at the request of dona Julia Orellana ${ }^{31}$ at the rest. ${ }^{32}$ In this case, the interruption was mandatory due both to the imposition by the agent and to the completion of the ritual unit. The second, on the following day, July 26: we resumed recording at 5:00 in the morning, filming the Luci-Luci, the Visitakuy and the miskipada. The interruption took place at the tasting of the "mondongo" 33 and at the end of the ritual moment. Finally, the third interruption, on the same day, at 2:00 PM, of the five ritual units performed in this phase: we filmed the first four, in other words, the preparation of the ritual table, the making of the wool ribbons, the Cintachikuy and the Casarakuy. These interruptions caused a filmic discontinuity of the ritual process, which was imposed by the ritual schedule itself and/or were imposed by the agents. In this way, we can see that the pauses made here were necessarily introduced by the filmmaker as a result of the programming established by the ritual and by the requests of the agent(s), dona Julia and "don" Juan.

2. Instrumental restrictions of observation. It is necessary to reiterate that

31 Dona Julia calls the attention of the participants, drunk or not, to her recent hernia surgery, vigorously asking for rest, for the next day's journey. This attitude and others would begin to create in me the clear perception of Dona Julia's matriarchal role in the household.

32 Faced with this "invitation", we judged it necessary to leave the location, not without first arranging our return for very early the next day. Dona Julia told us to return at around 2:0o in the morning, the time at which, according to her, the following ritual unit would start, called Luci-Luci.

33 Broth of dried cuzquenho corn, dried meat of bulls, pigs and sheep, dried skin and feet of pigs, tripe and other inardss. All these ingredients are boiled in their broth throughout the night. 
these restrictions are linked more to the process of observation itself than to the aforementioned observed ritual process. That is, the restrictions were particular to our mise en scène. Thus, the two sequences that enable us to show pauses or absences, inter-phases of an accidental or instrumental character, are the following: the first pause is attributed to the contingency of my own mise en scène. In the shift of the participants in the ritual toward the venue of the Huaca-Jorqoy ritual unit, to remove the huaca buried the previous year. We accidentally interrupted the recording, thus impairing the recording of one part of this ritual unit by fragmenting its duration. This pause is visible in the image, and is presented as an authentic jump in the ritual time and does not allow knowing its ritualistic duration. Another pause of an instrumental nature was created by the impossibility of adopting preventative measures related to technical production problems. Let us explain: on July 25, three ritual units were performed, the removal of the huacas, the Velakuy and the walks. We realized that, after recording the first two units, the portable battery became totally discharged. Thus, we knew a priori that we would not record the walks.

During the development of the filmed ritual, the two pauses mentioned above are displayed in an image as ellipses in the filmic time and space. However, the following reflection is fitting: in the first case (a contingency of my own mise en scène), the presence of these pauses and ellipses in the process shown does not substantially hinder the acquisition of understanding about this ritual unit. Meanwhile, in the second case, due to the technical problems already mentioned, we compensated for the lack of information in the audiovisual recording by registering the accidentally suppressed phase in the field journal. In addition, each time that the sequence of the ritual units was necessarily consecutive, we recorded their continuity. For example, on the main day, performed on July 26 , of the four ritual units, that is, the preparation of the ritual table, the making of the wool ribbons, the Cintachikuy and the Casarakuy, we recorded the beginning and the end of each ritual unit and their respective transitional phases - miskipadas or chaccheo. In this case, the presence of intra-phase temporal and spatial chains restores, in the process shown, the development of the obligatory sequences of the practices of the Santiago ritual. 


\section{Deferred observation and the point of view of the informant}

Regarding the (re)interpretation of the meanings of the Santiago ritual, this study not only sought to reflect on Andean culture based on an ethical interpretation, understandable to us as researchers, but, above all, proposes to see what others do and think, which a priori to us is alien., that is to say, we need emic elements to carry out this interpretation. Thus, as Geertz (1989) affirmed: "Societies contain their own interpretations. It is only necessary to discover the access to them." Of course, if anthropology has taught us anything, it is the complexity of this access. How is this access possible? We can preliminarily say that to be able to substantively work with these emic interpretations, we try to situate ourselves "from the native's point of view" ${ }^{34}$ (GEERTZ 1997: 89-107). In this sense, the dialog with the film has a hermeneutic scope, since it allows us to understand man's behaviors by using images to interpret them. Nevertheless, what appears in the image is not exactly the same as what is learned by direct observation. Thus, if the main problem resides in knowing how man enacts his gestures and symbolic behaviors, a methodological means is provided us to achieve that point of view: the study of man, with and in film ${ }^{35}$. As Claudine de France would say in defining the object of filmic anthropology: "Man as is apprehended by film, in the unity and diversity of the ways of staging his actions, his thoughts and his environment" (2000: 17).

We know that one of the particularities of videographic techniques is that they permanently fix a flow of fleeting manifestations. Therefore, in their restitution, they can be consulted in any situation and/or moment, be it by the filmmaker/anthropologist, by the informants or by both together. This possibility for feedback that the researcher has enables the immediate participation of the informants in the dialogs, testimonies and in the search for data and information, be supported in the examination of the recording. In other words, the interpretation of the data collected with the informants can

\footnotetext{
34 Recall, in the chapter about "Person, time and conduct in Bali" (GEERTZ 1989), and in the essay "From the native's point of view: on the nature of anthropological understanding" (GEERTZ 1997), that the author introduces us to an anthropological approach from the point of view of the informants. What is important to us is to discover together with the informant "what the hell they think they're doing” (GEERTZ, 1997: 89).

35 "The study of man by film means not only the study of filmable man - susceptible to being filmed - but, equally, the man filmed as he appears placed into the scene by the film." Claudine de France, "Antropologia Fílmica - Uma Gênese difícil, mas promissora," in Do filme etnográfico à antropologia filmica, Campinas, SP, Unicamp Press, 2000, p. 18.
} 
be mediated by what was observed and filmed and no longer by the sensorial, direct and immediate observation of the researcher, whose aids are the notebook and memory. Thus, a point of epistemological dialog is established between the cinema, with its deferred observation of Claudine de France (1988), and the anthropology "from the native's point of view" (hermeneutic) of Clifford Geertz (1997).

The Santiago ritual process was not totally unknown to us. While at other times $^{36}$ we had been present at similar rituals, for this study we decided not to consider our previous observations. We recall from our previous insertion: the understanding of the characteristics of the ritual (duration, repetition, places, succession of ritual units and their respective meanings) was nothing more than mere informal sketches and/or particular interpretations. Specifically, concerning the interpretations of the ritual meanings, our intention was to voluntarily refuse any information that diverted us from the course of our filmic observations and from the interviews with the people filmed. In view of this, it was indispensable to review the films with the people filmed and interview them as often as necessary. The examination of the recently shot tapes with the people filmed did not occur after the filming of each ritual unit or after each session of rituals. As mentioned, in the liminal phase, two reasons precluded the in loco analysis of the images: the fact that the people filmed were in a state of uninterrupted libation ${ }^{37}$ and the immediate succession of each ritual unit after the other. Thus, our deferred analysis was conducted on three fronts. On the first front, we took advantage of the moments of rest to see and review the film in the laboratory without the presence of the people filmed; the purpose was to survey the concrete symbols involved in the Santiago ritual. On the second ${ }^{38}$ front, based on the first observation, but, this time, with the presence of the people filmed, the appreciation and interpretation from the point of view of the informants of the ritual process filmed were conducted on the day after the conclusion of the entire ritual. As appears in the images, we gave space for a posteriori confrontation and dialog with the people filmed. Supported by the restitution of the fluent

36 As a university study and professor, I had many opportunities to conduct ethnographic surveys related to different cultural protests in the Rio Mantaro valley in the city of Huancayo, Peru.

37 The pauses were intended for the participants to rest.

38 It is from the second and third fronts of shared anthropology exchange with our informants that the contemporaneous anthropological reinterpretations about the Andean Santiago ritual arise. 
and persistent track of the ritual observed, the people filmed became their own observers, their own critics and, fundamentally, interpreters of their own symbolic behaviors. This is the epistemological bond between filmic anthropology and the anthropological practice: in the imagistic restitution, the point of view of the informant provides interpretations of the ritual, which in principle are alien to us.

We believe that interpretation from the point of view of the informants about what is observed is a complex task, since this procedure, in our case, initially involved a certain alterity on the part of the informants filmed. That is, the fact that the agents contemplated themselves not only allowed them to reencounter ritualistically lived moments and situations, but provoked a certain silence. We broke the ice of the initial self-consciousness of the informants by asking why they no longer went to the mountain to pick the flowers used in the ritual. Dona Julia immediately commented:

Before, although we were afarid of encountering the terrucos ${ }^{39}$ or the jarjária, ${ }^{40}$ when my daughters lived with me they always went to pick in the breaks of the mountains. Today my granddaughters are still small and my grandsons only think about drinking. Moreover, we can get them easier at the central market in Huancayo.

We thus have an example that gives us contemporaneous access to the reason why they did not acquire the flowers used in the Santiago ritual as they did before. We can see, in the example mentioned above, how they understand and act based upon their beliefs. We noted after this first dia$\log$, that our informants began to feel more comfortable when responding to our questions. The video was watched countless times. An incessant back-and-forth was established between the images of the tape and the oral and written commentary. In turn, on the third front, once again we continued in the laboratory to examine what was filmed. This time our aim was to isolate other cultural traits that might help us to understand or relate other element(s) of the cultural standard(s) made explicit in the ritual. It

39 Name used to refer to "terrorists" at the time of the Shining Path. Memories of life from when the peasants lived under fire. During the day, the military intimidation and bloody annihilation of peasants "suspected" of participating in the Shining Path sociopolitical movement and, at night, the bloody annihilation of the peasants "suspected" of collaborating with the military forces.

40 Transformation of incestuous people into animals. This subject will be dealt with later. 
was based on this third front for examination of the images that interesting questions were raised about propitiatory forms of bucolic behavior among the young participants in the ritual and the systems of learning as forms of cultural continuity. Although they are present in what was observed and filmed , they are not accessible at first sight, particularly those involving secret pastoral amorous ${ }^{41}$ behaviors.

In order to be able to interpret these new issues, we decided to return to the Torres Orellana family home to promote a new confrontation between the images filmed and our informants. Concerning the systems of learning, when the informants were interviewed, they were comfortable and readily explained their interests in the reason for the cultural requirement of continuing the Santiago ritual. Three moments of the Santiago ritual have essential importance: the floreo, the kinto (choosing the best coca leaves) and the selection and making of each animal's ribbons for the Cintachikuy (see page 16). We will take the first an an example: The floreo, which designates the making of the quille (the arch-shaped flower adornment). Its construction is a conciliatory act aimed at placating the ire of the Wamani. Three agents take part in this ritual practice: dona Julia (the initiator), two granddaughters (apprentices) and the device they are working with (the quille). The examination of the images shows the gestures made by dona Julia to make the arc of flowers and the at times distracted attention of the granddaughters when selecting the flowers. All the framings show how dona Julia removes the dry flowers that had been placed in the arc in the previous ritual and gradually replaces them with fresh flowers. The selection of the best flowers is the responsibility of the granddaughters, who at times, distracted by the drunk participants, do not strictly follow dona Julia's gestures. In this initiation relationship, a conflict is apparently established in the transmission and acquisition, with both parties seeming to "lack commitment." This sparked our first questions: why didn't dona Julia ask the granddaughters to pay better attention to the preparation of the quille? If the entire initiation relationship requires a certain level of communication between its participants, why were the granddaughters at times so distracted? However, when we asked them why they didn't pay

41 Santiago is made up of a series of familial agrarian rituals related to greater or lesser cattle. Thus, the Santiago festival is considered a day for the animals and those who tend them. Consequently, the behaviors belonging or related to the amorous relationships linked to the life and the customs of the field and the shepherds can be called bucolic love. 
more attention to making the quille, the response was immediate: "my grandmother (dona Julia) always taught us, always [do it] patiently, now we know, so we always help." The fact that they said "we already know," indicates there existed a previous moment. Effectively, the granddaughters' apparent "lack of commitment" is only explained if we refer to a particular temporality of knowledge. - Learning never takes place at only one time. That is, some ritual teachings had already been transmitted in past sessions by dona Julia.

To confirm this, we asked dona Julia the reason for the lack of zeal in transmitting her knowledge to the granddaughters, and she very angrily responded:

It's not a lack of concern! They already know! My granddaughters have been learning from me since they were younger, in the same way my daughters learned, my mother taught me and she learned from her mother (my grandmother). So, the offerings to the Wamani can never die, otherwise we could lose everything, my cattle could die. It cannot end or the Tayta Wamani would punish us.

Consciously, dona Julia knows that she had various sessions for teaching her granddaughters. Thus, the testimonies of dona Julia and of her granddaughters led us to think that any transgression, distraction and unsatisfactory results previously practiced by the granddaughters had been corrected and transmitted by the source of the initiation (dona. Julia) in the annual repetition of the ritual.

However, when we review some isolated scenes about amorous behaviors between two of the participants (Rosa and Pedro), dona Julia reacted violently and removed herself from the room where the video was being projected. But after a brief silence don Juan, offered to comment on the scenes. Since they are isolated in time and space, we made use of the notes recorded in our field notebook to refer to the backstage elements of the ritual process observed and of the ritual process filmed. Thus, we reminded don Juan about his reprimand of his nephew and niece (Pedro and Rosa) for the behavior they demonstrated on the night of July 25 , during the walks and when visiting their neighbor, dona Mirta and on July 26, the main day.

For a better understanding, I will summarize the kinship relationships between Don Juan's niece and nephew. Since Pedro is the son of a parallel cousin of don Juan and Rosa is the daughter of don Juan's daughter both are 
partilinear cousins and nephews and nieces of don Juan. Through our own observations, we know that the romantic exchanges between Pedro and Rosa began on July 25 during the night of the Velakuy. They resumed on July 26 , the main day, between the rituals of the blessing table and the Cintachikuy. While they danced, we see in the background of the image of the film recordings of this day that Marco (the son of don Juan's older brother and thusanother nephew of don Juan; Rosa's cousin), perceiving the mutual gallantry. $\mathrm{He}$ separated the girl rather harshly and without saying anything began to dance with her. Pedro seems not to understand Marco's attitude. Isolated between the ritual table and the circle of young men, he demanded explanations saying: "Son of a bitch, why did you leave me dancing alone, why don't you want me to dance with her" (sic). These reproaches by Peter yield a replica of insults and offenses from Marco, who responded: "Son of a bitch, you know you can't, this is my house" (sic). As the image accompanies the developments of the ritual blessing table, the unfolding of the discussion is interrupted and we do not know how the cousins, Pedro and Marco, solve this impasse. The questions arise, what does Marco mean when he says "you know you can't?" And further: what sparked the discussion between the cousins. When the images were shown, Dona Julia left the house angrily uttering a mixture of Quechua and Spanish. Nevertheless, don Juan, slightly troubled, tells us that "this could result in jarjária." But, what defines jarjária? What myth or oral narrative could help us to penetrate the meaning of jarjária?

In short, from our studies, we know that kinship serves to establish inheritance, institute relationships of assistance and cooperation and cement social control to avoid incestuous relationships. Above some laws that prohibit union among community members, there is a supernatural rule that prohibits incest. It is so broad that it includes all consanguineous relatives, and those of affinity and "spirit" (compadres). This study found the subsistence of a penalty that threatens punishment against individuals who participate in incest. According to "don" Juan Torres, the belief of jarjária, via the myth of the Huída Mágica (magical escape), ${ }^{42}$ explains the penalty for people engaged in incest. Thus, by combining the information found in the third front of the deferred observation and by the field book notes of the backstage, don Juan

42 To know their version of this, and thus be able to understand this fear of incest, I refer the reader to 'A fuga mágica: o horror ao incesto,' in chapters IV and V of my Doctoral thesis "O ritual andino Santiago: uma Reinterpretação etnocinematográfica.” Unicamp, Campinas, 2003. 
clarified the reason his family and his community rejected the amorous behavior of his nephew and niece. In this case, he refers to the narrative of imaginary happenings - the myth - that symbolize the forces of nature and/or the aspects of bucolic amorous life in the Auray peasant community.

Some reflection on this issue is certainly due. Roughly speaking, direct observation, based on verbal language and memory, has the ability to capture some of the ritualistic manifestations present in the Santiago ritual. However, it tends to retain only the more relevant facts that are readily recorded in writing. Thus, the description of these facts will be restricted to fragments of a larger referential frame. In compensation, the filmic continuum of the ritual, complemented by countless examinations of the film, allowed us not only to recognize in detail the nuances of gestures, actions, behaviors and continuous ritual happenings, but, from this same uninterrupted mise en scène, reconstitute the complete real density of the indiscreet and subtle behaviors. The latter, despite being present in the images, were not intelligible and communicative at first sight. A first viewing notably obeys the forms as they present themselves, that is their auto-mise en scène. In this case, the repeated examination of the film, more than necessary, is absolutely essential. Because of this specificity we were led to explore what was present in the image, although not continuously highlighted, as in the case of the romance between Pedro and Rosa, because they were not the main actors/informants/addressees of our strategy and observation guides of the ritual.

In addition to this, since any cinematographic capture is submitted to the scenographic laws of exclusion and saturation ${ }^{43}$, every filmic description, by the framing used, selects the autonomous mise en scène in which the actors of the ritual filmed display to the camera of the anthropologist/filmmaker their acts and the things that are involved in a obvious or secretive way, during their ritual activities,. Since the gestures, activities and behaviors of the Santiago ritual are subordinated to a pre-established program that commands their overall execution: the rhythm, the duration, the rules of composition, of sequencing and ordering the phases of what unfolds, we agree "that a part of the things (actions, objects, happenings) inevitably escapes this description

43 "Law of exclusion: showing something means hiding something else, simultaneously; law of saturation: showing something means showing something else simultaneously." See Xavier de France, Eléments de scénographie du cinema, Nanterre, Université Paris X-FRC, 1982. 
[...], by being camouflaged, shaded ${ }^{44}$ or excluded from the filmic scene" (DE FRANCE 1998: 30). So, despite our methodological attitude seeking to fill the image with the maximum of symbolic references from the Santiago ritual, by means of framings, angles, and the duration of the planes, some elements of the manifestation filmed were excluded from the filmic images. Two examples of the exclusion of these elements are particularly interesting: the first, the placing of coca leaves on the plate in the Cintachikuy ritual unit. In the preparation of the ritual blessing table, dona Julia, her daughter and granddaughters performed three activities: the chaccheo, the kinto and the selection and preparation of the ribbons for each animal. In the practice of kinto, our study observed that dona Julia's daughters and granddaughters selected the best coca leaves. In this activity, every time that a leaf is dipped in the cachaça, a request is made to Apu Huaytapallana and Pachamama (Mother Earth) for the reproduction of the cattle. Now in the Cintachikuy ritual, as the young walars mark the cattle, Rosa enters and leaves the scene several times with the plate containing the kinto and the cachaça,. Initially, nothing indicates that her presence in this ritual unit is essential, because the majority of the participants of the ritual are present just as she is. It is for this reason that the examination of the recordings is indispensable. Thanks to this repetition we were led to explore what was present in the image but not highlighted by our mise en scène. Thus, after distinguishing Rosa's shaded presence, a dialog with our informants was necessary. When we asked don Juan what the significance of this practice was, he told us: "It is the offering to the Wamani, for my animals to be good breeders." This belief is explained by a homeopathic type of act. Because the kinto leaves symbolize the cattle as a whole; the plate with chicha (symbolic serum) fulfills the function of protection against illnesses from the Wamani; and its separation at the edge of the plate serves as a count of the animals that will be breeders, far from the reach of disease. Thus, we learned that her participation is key to the Cintachikuy, since the gesture of placing a coca leaf at the edge of the plate signifies not just a form of calculating the marked animals, but, above all, as a sign of purification of the cattle.

In the same way, how could the amorous behavior mentioned between

44 "Vanishing, whose term we borrowed from the technical vocabulary of pictorial art, consists of displaying in a relatively erased manner, out of focus, marginally or too quickly, some elements delimited by the image, in such a manner that they pass unseen by the spectator." See Claudine de France, Cinema e antropologia, Campinas, SP, Unicamp Press, 1998, p. 413. 
Pedro and Rose, at the moment of preparing the ritual blessing table prior to the Cintachukuy, be identified amid the variety of tasks particular to this phase of the process? Especially since, nothing in the phases prior to the preparation of the ritual blessing table created suspicion about a romance between Pedro and Rosa, other than their behavior during the walks. Since the image accompanies the process of the ritual unit of this moment, we intermittently and discontinuously see, entering and leaving the filmic scene, the sudden argument between Marco and Pedro. Thus, the argument is introduced, in part, without revealing its nature to the spectator. A precise understanding of many of the passages of this discussion is not possible solely by means of the filmic images, due to the guiding focus that we chose for our mise en scène. The focus was on the actions that command the ritual process and the activities subordinated to it. Therefore, it was not our intention, while filming, to emphasize any sudden conduct and reactions alien to the process. The two examples presented here, although they permeate the entire process, are not accessible or apparent at first sight. This is due in part to the way that they are manifested and placed in scene. ${ }^{45}$

\section{Santiago: assembling the video}

In the desire to make "O Santiago" a video with a descriptive vocation, we chose to limit our editing time to the ritual sequences judged essential to understanding the ritual process. In addition, our editing strategy led us to eliminate ${ }^{46}$ from the image aspects and phases of the process that, depending on a different focus, are not directly useful to understanding and demonstrating the ritual process. That is, we excluded most of the peripheral or ancillary activities of the agent(s). For example, several secondary sequences of the ritual activity in which the image follows the unfolding of gestures of

45 François Truffaut said that people always see on a general plane, the contrary happens every time we see through the camera lens, since we can select the plane, that we wish to select/show. This selection divides the space in two planes: what is seen and what is not seen. That is, the use of the camera demands a selection of space (framing) and presupposes leaving part of reality out of the frame (outside the field). This principle functions in the following way "framing is admitting inside the field and simultaneously rejecting the outside the field." Thus if showing something means simultaneously hiding something else, we are speaking of a present space and an absent space. In our case, it is the present space that interests us. Declaration from Alfred Hitchcock to François Truffaut in, François Truffaut. El cine según Hitchcock, Madrid, ed. Alianza, (1998).

46 Not as an arbitrary act, but rather a narrative option of describing the ritual process. 
the participant(s), such as in the miskipadas and the rest periods.

Audiovisual recordings of the corresponding testimonies of our informants are also not present in the final cut. The principal reason was the lack of a second video camera that would allow recording the gestures of the informants as they were watching the images of themselves, but also the narratives of their myths and their symbolic behaviors. We needed our only video camera to reproduce the recordings. The camera was connected to a 14 " TV monitor placed in front of our informants to display the recorded images of the ritual. In the presence of the image, we established a dialog and a critical examination of their behaviors. It was thus technically impossible to record the testimonies of the informants as they watched the film. This testimony was noted in our field journal.

In the final cut, we decided to join the planes in such a way that the end of the first and the beginning of the second showed, respectively - sometimes from different points of view - the beginning or the end of a gesture or a ritual activity. However, since all the ritual units of the Santiago ritual are unintelligible without the contribution of verbal commentary or the use of what Claudine de France (1998) calls extracinematographic resources, ${ }^{47}$ we opted to insert a general introduction about the ritual and divided it into consecutive ritual units that are announced via introductory captions. These captions were later combined with the image, and were presented together for the final agencying of the images. This editing strategy ${ }^{48}$ allowed us to transform the video "O Santiago" into a medium for of echnical and social relationships whose flow, and the simultaneity of six hours of information would be impossible to describe. In this sense, our experience is an attempt

47 "A commentary about the form of locution of texts, fixed or animated schemes, diagrams, animated models, abstract structures, mathematical symbols." Claudine de France, Cinema e antropologia, Campinas, SP, Unicamp Press, 1998, p. 386.

48 In her intent to know new forms of exposure that reconcile the advantages of exploratory discovery with those of classical exposition, the author Claudine de Frances helps us understand what she qualifies as post-exploratory forms of exposition or even neo-exposition. This neo-exploratory form of exposition, according to de France, is when "traits discovered in the image are conserved in the process observed, which orient the mise en scène of the definitive film (...) in the same way, aspects and phases of the process that present less interest to the demonstration are abandoned, but can figure into another part of the definitive film. The selection operated by the neo-exposition film differs from that of classical film by necessarily emphasizing the most impressive or the most spectacular aspects or phases of the process. Weak time and dead times are eliminated since they lead the spectator on new paths, and not because they delay the action." Claudine de France, Cinema e anthropologia, Campinas, SP, Unicamp Press, 1998, p. 386. 
at making a synthesis between the logic of discovery of the exploration film and the presentation of the results.

\section{Some observations about filmic anthropology}

It has been ninety years since Robert Flaherty first showed Nanook; since then, many other films and recently many videos have been made that show and describe "other" cultures. However, only some of these achievements were prepared with a basis in what made Nanook one of its principal examples. Two cultural modalities are somehow joined together in order to observe both everyday life and the means derived from systematized knowledge. Flaherty's choice in his film was probably the first step to introduce the communication media (cinema, video and photography) to the acquisition of anthropological knowledge. Through this knowledge, peoples have faced the challenge involved in representing their own histories and culturesa and anthropologists use audiovisual tools to try to reconstruct cultures in the direction opposite to the processes of acculturation, and promote elements of traditional behavior for posterity, or to analyze different cultural phenomena supported in the images as a revealing source of anthropological discovery.

It has also been more than half a century since André Leroi-Fourhan (1948: 42-50) presented his work "Le film etnographique existe-t-il?" to the Congrès International du film d'Ethnologie et de Géographie, an article that according to Claudine de France, marked the birth of ethnographic film. The integrity and constitution of ethnographic film were once bleak, but today it is resurgent, above all in the academy, where a series of proposals has emerged that enable theoretically and methodologically clarifying and establishing the horizon of ethnographic film. For this reason, based on our videographic experiences and analyses, we would like to make some epistemological considerations about filmic anthropology in anthropological practice. We do not have the pretense of conducting a comprehensive review, but simply offering some observations.

Filming is not in any way the same as researching. Regarding observation, the notebook and interviews, are means for reflecting that are different from filming. Observing the filmed material is not the same as classifying and systematizing field notes, unless the audiovisual in anthropology is applied -as it indeed is - to studies that contemplate ritual descriptions, 
technical operations, rhythm and movement, spatial descriptions, cultural relationships and cultural manifestations. In this case audiovisual media, therefore, offer the best means to capture and perceive, from another angle, the symbolic interpretations of the producers of meaning. This establishes an intimate relationship with Clifford Geertz's concern that; “a self-consciousness about the modes of representation has been missing from anthropology" (1980: 30). Geertz refers to the task of "inscribing," which the researcher should perform not just in field research, but in the modes of representation, since according to him, a large part of ethnography is only found in books and articles, and not in films, photographs, drawings and charts.

The benefits granted by deferred observation are evident because the participation of the people filmed in the constant repetitions ensures better use of the recorded material. However, it is necessary to emphasize that this methodological principle will fundamentally depend on the nature of the social phenomenon recorded. This nature, inscribed in the topic of the study, will determine whether the intervention of the informants is necessary. Not every application of audiovisual media in anthropology can be subject to the application of feedback. This methodological spirit was certainly not applied in the recordings of Robert Gardner, in Dead Bird. On the other hand, people filmed are not always ready to inform and or comment, either to analyze their own image and behavior, or to comment on collective images or behaviors, because other people, other individuals are involved. When this is the case, it will depend, on the one hand, on a certain degree of consciousness on the part of the observed with respect to what the observer intends with his a posteriori participation in the recording process itself. Nevertheless, if this recording process altered their behavior, the torture to which they are subjected by the constant repeated visions of the images ends up frequently upsetting the informants. Thus, ethical considerations are raised that make it important for every researcher to provide his informant/participant an "overall" explanation of the research process. As a result of this attention, the voluntary consent of the informant and the mutual respect between observer and observed/participant are contemplated, in order to achieve the objectives sought. In deferred observation, this relationship of sharing between observer and observed of the imagistic recordings becomes essential, provided that they are performed at the first moments of analysis. However, we believe this strategy, is more valid and relevant based on analyses from the perspective of 
both the anthropologist and the filmmaker, or since that which is observed and filmed is accompanied by other dialogic and polyphonic points of view (CLIFFORD \& MARCUS 1986), which are interested in the given social phenomenon. From the information obtained through these fine analyses of the images, the material for the written text arises, to support that which was observed and filmed. In this case, the writing is submitted to the image.

Concerning filmic anthropology, from the theoretical-methodological perspective of the University of Paris X, Nanterre - "Formation de Recherches Cinématographiques" (FRC) - "Training in Cinematographic Investigations" - particularly in the line of works by Claudine de France, which is supported by the repetition of the observed process (the sketches method), of its recording and the examination of the image in the company of the people filmed, is the foundation of the exploration film, which transforms film from a simple spectacle into a research tool. Critics of de France's proposal raise three issues and she refers to two of them. The first originates from the fact that the "repetition of the sketches tends to have the presentation indefinitely remove itself from a finished, demonstrative and synthetic product" (DE FRANCE 1989: 350). As a consequence, the logic of presentation is sacrificed in favor of that of discovery. She also recognizes that this method is reduced "preferentially to everyday processes, to mechanical gestures familiar to the anthropologist/ filmmaker, that is, to the most common acts of his own society" (Op. Cit.: 350). Moreover, in addition to being too costly, to crystalize, the sketches need the process to be repetitive and of short duration, and we know very well, this does not always happen. This is the case of our video "O Santiago" due to its extensive seasonal ritual process and its division into ritual units, the videographic recordings suffered from a series of temporal and instrumental contingencies, which prevented the precedent methodological spirit from being applied. Nevertheless, all these arguments call into question the entire reflection about, for example, the secondary position that could and should be conferred to direct observation. The innovative character of Claudine de France's reflection and proposal, which definitively places the theoretical and methodological problems of ethnographic cinema in the specific context of its working medium, still seems to us, to be of undeniable interest.

Finally, there is an urgent need to learn about both production and reading of the audiovisual tools for collecting imagistic data, because ignorance of the cinematographic language is an obstacle both for users who seek to 
undertake this technique and for anthropologists who analyze the results. As David MacDougall affirms:

When we resort to film, we should know whether it is as a method of field work or as a simple means of publication, because producing a film is not as much knowing how to look through a camera as seeing what is on the screen. (1994: 72).

The author intends to say, as we understand well, that every anthropologist must also be concerned with learning about the factors particular to cinematographic, videographic or photographic reading, implicit in these media. In this sense we agree with Jean Rouch (1968) and Marc Piault (2000) when they express that one of the challenges of ethnographic film is to combine the rigor of scientific investigation to the art of cinematographic presentation.

\section{Bibliography}

BANKS, Marcus. 1998. "Visual anthropology: image, object and interpretation”. In: Jon Prosser (ed.), Image-based research. London: Falmer Press. pp. 9-23.

CAZENEUVE, Jean. 1971. Sociologie du rite. Paris: Presses Universitaires de France.

CLIFFORD, James \& MARCUS, George E. 1991. Retoricas de la antropologia. Barcelona: Júcar.

ELIADE, Mircea. 2001. O sagrado e o profano: a essência das religiões. São Paulo: Martins Fontes.

FRANCE, Claudine de. 200o. "Antropologia fílmica - uma gênese difícil, mas promissora”. In: Do filme etnográfico à antropologia filmica. Trad. Marcius S. Freire. Campinas, SP: Editora da Unicamp. pp. 17-35.

FRANCE, Claudine de. 1998. Cinema e antropologia. Trad. Marcius S. Freire. Campinas, SP: Editora da Unicamp.

FRANCE, Xavier de. 1989. Eléments de scénographie du cinema. Nanterre: Université Paris X - FRC.

GEERTZ, Clifford. 1989. A interpretação das culturas. Rio de Janeiro: LTC.

GEERTZ, Clifford. 1980. Negara: the theatre state in nineteenth-century Bali.

Princenton: Princenton University Press.

GEERTZ, Clifford. 1997. O saber local. Novos ensaios em antropologia interpretativa. Petrópolis: Vozes. 
GENNEP, Arnold van. 1977. Os ritos de passagem. RJ: Vozes.

HUSCH, Luc de. 1974. "Introduction à la ritologie genérale”. In: Edgar Morin et Massimo Piattelli-Palmarini (eds.), L'unité de l'homme, invariants biologiques et universaux culturels. Paris: Éditions du Seuil. pp. 679-713.

JANCKINS, Ira. 1988. "Margaret Mead and Gregory Bateson in Bali: their use of photography and film". Cultural Anthropology, 3(2): 160-178.

LEROI-GOURHAN, André. 1948. "Cinéma et sciences humaines - le film ethnologique existe-t-il? ”. Revue de Géographie Humaine et d'Ethnologie, 3: 42-50.

LYDALL, J. 1992. "Filming the women who smile”. In: P.I. Crawford \& J.K. Simonsen (eds.), Ethnographic film: aesthetics and narrative traditions. Aarthus: Interventions Press, 1992. pp. 147-158.

MACDOUGALL, David. 1992. “Whose story is it?”. In: P. I. Crawford \& J. K. Simonsen (eds.), Ethnography film: aesthetics and narrative traditions. Aarhus: Interventions Press. pp. 25-42.

MACDOUGALL, David. 1994. "Mas afinal, existe realmente uma antropologia visual?”. Catálogo II Mostra Internacional do Filme Etnográfico. Rio de Janeiro: Interior Produções. pp. 71-77.

MACDOUGALL, David. 1998. Transcultural cinema. New Jersey: Princeton University Press.

MACHIN, Barry. 1988. "Video and observational of complex events - the new revolutions". Glasnik. Bulletin of Slovene Ethnological Society, 28: 64-68.

MALINOWSKI, Bronislaw. 1976. Argonautas do Pacífico Ocidental. Um relato do empreendimento e da aventura dos nativos nos arquipélagos da Nova Guiné melanesia. São Paulo: Pensadores.

MORPHY, Howard. 1994. Rethinking visual antropology. London: Yale University Press.

PIAULT, Marc-Henri. 1994. “Antropologia e cinema”. Catálogo II Mostra Internacional do Filme Etnográfico. Rio de Janeiro: Interior Produções. pp. 62-71.

PIAULT, Marc-Henri. 2000. Anthropologie et cinéma. Paris: Editions Nathan/HER. POLIA, M. Mario. 1999. La cosmovisão religiosa andina en los documentos inéditos del Archivo Romano de la Compañia de Jesús (1581-1752). Lima: Fondo Editorial/ PUCP.

QUIJADA, Sérgio. 1974. Tayta Shanti. Huancayo: Edit. Sebastian Lorente. REYNA, Carlos. 2003. “(Re)interpretação contemporânea do ritual Santiago”. 
Resgate - Revista de Cultura, 12: 23-41.

REYNA, Carlos. 2006. “Os deuses da montanha do Peru contemporâneo”.

Cadernos de Antropologia e Imagem, 23(2): 137-153.

ROUCH, Jean. 1993. “'Os pais fundadores' dos 'ancestrais totêmicos aos

pesquisadores de amanhã'”. Catálogo I Mostra Internacional do Filme

Etnográfico. Rio de Janeiro: Interior Produções. pp. 14-20.

ROUCH, Jean. 1979. "La camera et les hommes”. In: Claudine de France (org.),

Pour une anthropologie isuelle. Paris: EHSS. pp. 53-71.

TURNER, Victor. 1978. O processo ritual: estrutura e antiestrutura. Petrópolis:

Vozes.

GARCILAZO DE LA VEGA, Inca. 1970. Comentarios reales de los Incas. Lima:

Universo.

\section{Filmography}

ROUCH, Jean. Architectes Ayorou, CNRS/CFE, 1971, 16mm, colorido, 30'.

GARDNER, Robert. Dead Birds, DER, 1964, 35mm, colorido, 83'.

REYNA, Carlos. O Santiago, LAVIDOC/UFJF, 2003, video tape, 14'.

\section{About the author}

Bachelors in Social Sciences at UNCP (Universidad Nacional del Centro del Perú), with Masters and Doctorate in Multimedia/Cinema at the Universidade Estadual de Campinas, in 2003. Post-Doctorate at the Universidade Federal de São Carlos. Since 2010 he has been a professor of Visual Anthropology in the Graduate Program of Social Sciences (PPGCSO), adjunct professor II of Cinema at the Institute of Arts and Design at the Universidade Federal de Juiz de Fora and coordinates the Visual Anthropology and Documentary Group (LAVIDOC/CNPq). In his research he uses ethnographic film as a method in the anthropology of visual systems and/or visible cultures, fundamentally, rituals. He is the author of many articles that reflect on the dialogs between Anthropology and Cinema.

Translated by Jeff Hoff

Text received April 30, 2012. Approved June 30, 2012. 